\title{
Exploration of Bael (Aegle marmelos) Fruit Extract as Prebiotic for Development of Probiotic Chocolate
}

\author{
K.R. Sawale*, H.W. Deshpande and S.D. Katke \\ Department of Food Microbiology and Safety, College of Food Technology, \\ VNMKV, Parbhani, India \\ *Corresponding author
}

\section{Keywords}

Prebiotic, Lactic acid bacteria, Probiotic chocolate, Bael Fruit Extract, Aegle Marmelos, Lactobacillus acidophilus, Lactobacillus bulgaricus

Article Info

Accepted: 12 March 2019 Available Online: 10 April 2019
Encapsulation of chocolate with viable cells of lactic acid bacteria (LAB) and development of modified technology of chocolate manufacturing to provide survival of these bacteria would contribute to enhanced beneficial impact of this product on human health. This approach is of importance because chocolate is one of favourite food stuffs for children. Because the unique taste of chocolate is particularly valuable for consumers, its sensory attributes should remain unaltered despite the addition of preparation of lactic acid bacteria. Due to synergetic effect of bael fruit extract and probiotic culture i.e. functional probiotic chocolate was prepare by using prebiotic source.

\section{Introduction}

Bael (Aegle marmelos) is an important indigenous fruit of India and has great mythological religious significance. The tree holds a sacred value among Hindus and is often worshipped or its leaves are presented to the deities. Bael is an important drought resistant and hardy fruit plant of semi-arid and arid regions. However, it can grow on a wide range of soils and can tolerate temperature as low as $-7^{\circ} \mathrm{C}$ and as high as $48^{\circ} \mathrm{C}$. Therefore, it is ideal for dry land horticulture. Bael fruit (Aegle marmelos Correa.) has a long history of use in traditional medicine, much of which is being validated by scientific research. Bael is an important tropical medicinal plant which possesses various medicinal properties. It is native to India having origin from Eastern Ghats and Central India. It is grown throughout India with altitude 1200 meter as well as in Sri Lanka, Pakistan, Bangladesh, Burma, Thailand, and most of the Southeast Asian countries. It is native to India (Morton, 
1987). In recent times, the attention on plant research has tremendously increased all over the world and a genuine number of evidences have collected to show immense potential of plants used in various food and pharmaceutical applications. The hydrocolloidal form of polysaccharide including mucilage, gums and glucans are abundant in nature and commonly found in many higher plants. These polysaccharides are structurally diverse class of biological macromolecules with a broad range of physicochemical properties and widely used for various applications in pharmacy and medicine (Iyer and Kailasapathy 2005). The plant-based polymers have been applied in different pharmaceutical dosage forms like matrixcontrolled system, film coating agents, buckle films, microspheres, nanoparticles, viscous liquid formulations like ophthalmic solutions, suspensions, implants and their applicability and efficacy has been proven. Polysaccharides are also being utilized as viscosity enhancers, stabilizers, solubilizers, emulsifiers, suspending agents, gelling agents and bio adhesives binders. (Krasaekoopt et al., 2003) Industrial gums and mucilage, which are generally water-soluble polysaccharides, have enormously large and broad applications in both food and non-food industries. Due to their unique physicochemical properties and often at costs below those of synthetic polymers these are frequently used as thickening, binding, emulsifying, suspending and stabilizing agents in pharmaceutical industries (Anuradha and Rajeshwari 2005)

An increasing demand of consumers for foodstuffs supplemented with live LAB, preferentially probiotic ones, gave rise to studies on the enrichment of some other foods with these microorganisms. Confectionery products provide for consumers calories and sweetness (organoleptic properties) while usually having no added value. The development of new technologies facilitating the supplementation of confectionery with LAB can yield novel products, enriched with health-promoting ingredients that can prevent civilization disorders. Because confectionery products are consumed by children and teenagers, their supplementation with live LAB is advisable. The basic criterion of quality evaluation of this sort of products should be the maintenance of LAB cells at a functional level during technological processes and throughout the storage at ambient temperature. The acceptance of sensory attributes by consumers is also of a great importance and therefore these products should have the same sensorial characteristics as the traditional LAB free ones (Burgain et al., 2011)

Encapsulation of chocolate with viable cells of lactic acid bacteria and development of modified technology of chocolate manufacturing to provide survival of these bacteria would contribute to enhanced beneficial impact of this product on human health. This approach is of importance because chocolate is one of favorite food stuffs for children. Because the unique taste of chocolate is particularly valuable for consumers, its sensory attributes should remain unaltered despite the addition of preparation of lactic acid bacteria.

The chocolate encapsulated with viable cells of lactic acid bacteria, displays nutritional and health benefits, and can be regarded as a functional foodstuff. To address the demands of consumers, the novel technique of making chocolate which is enriched with encapsulated cells of lactic acid bacteria has been developed (Maillard and Landuyt, 2008)

The aim of research is to evaluate the feasibility of using chocolate as a carrier for a microencapsulated Lactobacillus strain. In the view of the importance of Bael (Aegle 
marmelos) fruit as a therapeutic, medicinal, and nutritional value and it act as a prebiotic therefore an urgent need to develop the processing technology of this neglected but valuable fruit into different commercial valueadded products having extended shelf life (Cardarelli et al., 2008).

Because of its hard shell, mucilaginous texture and numerous seeds in pulp are difficult to eat in raw state, and hence, it is not popular as Table fruit. The fruit has rich aroma, which is not destroyed even during processing, thus, it has great potential for processing into several products. Hence, the present investigation and efforts towards this vein undertaken to standardize the processing technology for the preparation of probiotic chocolate by using Bael fruit extract as prebiotics. This research has been taken for development of Probiotic chocolate by using microencapsulated Lactobacillus species to confer the health benefits (Nazzaro et al., 2012)

\section{Materials and Methods}

\section{Collection of material}

Raw materials like Bael fruit, cocoa powder, sugar powder, butter, skimmed milk powder, and emulsifier collected from local market. Microbial culture was collected from department of Food Microbiology and Safety, College of Food Technology, VNMKV, Parbhani.

\section{Preparation of Bael water extract}

For the preparation of water extract of Bael, semi ripe/ripe fruit were used. The shell was broken, and the pulp was mixed in water at the concentration of $10 \mathrm{~g} / 100 \mathrm{ml}$. To smoothen the solution the pulp was crushed, and seeds were removed and it was strained through a muslin cloth.

\section{Isolation of probiotic culture}

Curd and yoghurt samples were used for isolation of probiotic LAB cultures. From each sample, 1:10 serial dilution was subsequently made using sterile normal saline $(0.85 \%)$ followed by making a 10 -fold serial dilution. Then $0.1 \mathrm{ml}$ from each dilution was sub-cultured aseptically on MRS agar using pour plate technique. All the plates were then incubated at $37^{\circ} \mathrm{C}$ for $24-48$ hours. Isolated colonies were selected and inoculated into MRS broth and incubated for 24 hours. After vigorous growth of culture, it is again inoculated on MRS agar to get pure culture.

\section{Preparation of stock culture}

After identification, the pure cultures i.e. Lactobacillus acidophilus and Lactobacillus bulgaricus were cultured on MRS media slants. This was incubated at $37^{\circ} \mathrm{C}$ for 48 hours and stored at $4^{\circ} \mathrm{C}$ for further use.

\section{Starter culture}

The probiotic organism's viz. Lactobacillus acidophilus and Lactobacillus bulgaricus were individually grown in MRS broth at $37^{\circ}$ $\mathrm{C}$ for $48 \mathrm{~h}$. The cultivated MRS broth was then centrifuged at 4,000 rpm for $10 \mathrm{~min}$ to harvest the cells. The harvested cells were washed twice with sterile water. The biomass was taken as starter culture.

\section{Preparation of beads}

$3 \%$ Bael Fruit extract and $1 \%$ sodium alginate and $0.03 \mathrm{M}$ calcium chloride solution. Bacterial sample was added to the polymer solution and the solution was homogenized using vortex. This solution was added drop wise using a syringe with needle diameter of 1-5 $\mathrm{mm}$ to the calcium chloride solution. Interaction between the two solutions led to formation of beads $(2-5 \mathrm{~mm})$. 
The capsules/beads formed were allowed to harden for 10 minutes, washed in de ionized water twice and spread on a petriplate to dry.
Beads were then stored in $0.1 \%$ peptone solution at $4^{\circ} \mathrm{C}$.

Flow Sheet 1: Microencapsulation of strains

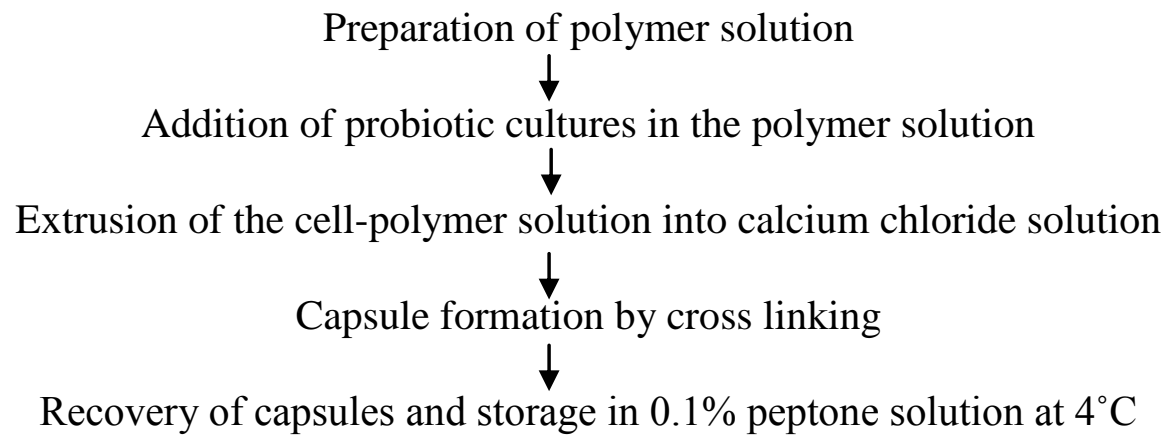

Flow Sheet 2: Processing technology for probiotic chocolate

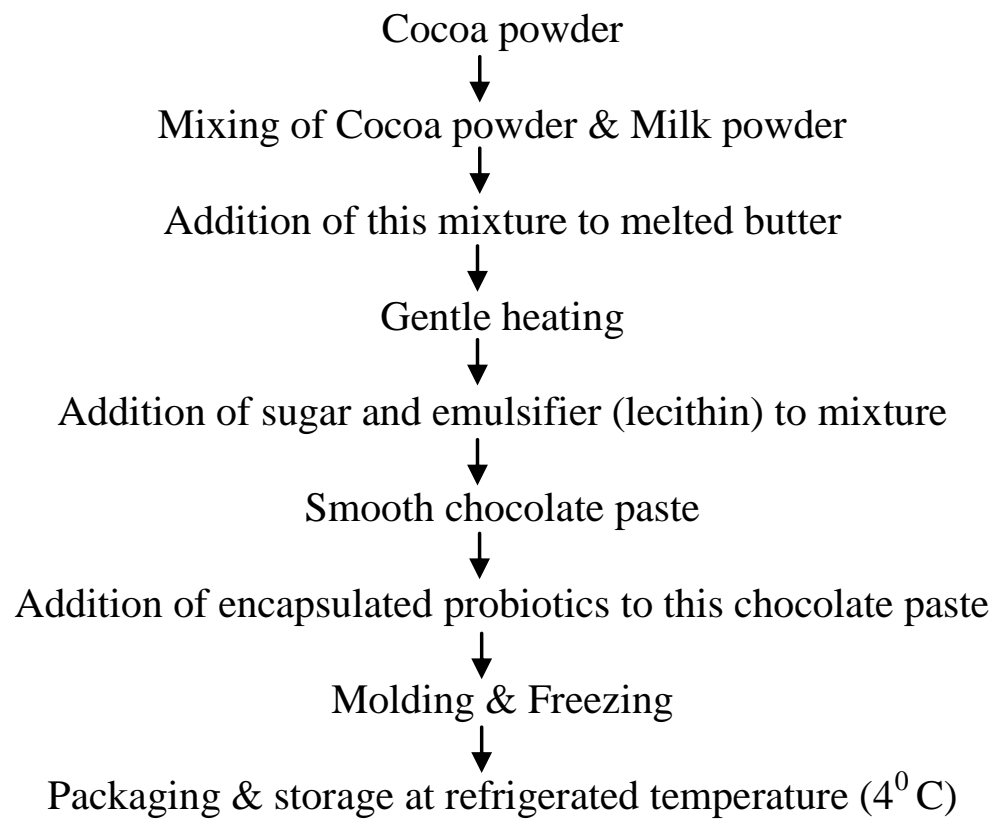

\section{Results and Discussion}

Data showed in Table 1 revealed that the chocolate sample contained $5.64 \%$ moisture, $6.81 \%$ crude protein, $31.73 \%$ crude fat, $51.27 \%$ carbohydrates and $2.43 \%$ crude fiber. It was observed that the protein content of chocolate $(6.81 \%)$ was comparatively less than the protein content of cocoa powder
$(8.50 \%)$ and skimmed milk powder $(35.5 \%)$ This may be as a result of the heating process which could have denatured some protein in the chocolate (Ndife Joel et al., 2013)

It was observed that the fat content of chocolate was much higher $(31.73 \%)$. The significant increase in the fat content of chocolate was as a result of the contribution 
of ingredients added in the production of chocolate such as butter, milk powder. Fats, especially the unsaturated fat are prone to oxidation and shorten shelf-life of food products.

The ash content of probiotic chocolate was $2.12 \%$. Ash is an indication of mineral contents of foods and has been shown by Ieggli et al., (2011) to be high in cocoa products. It is observed that chocolates are good sources of minerals, specifically calcium, magnesium, copper and iron.

The observations from Table 2 revealed the mineral content of probiotic chocolate. Calcium content of probiotic chocolate was $(1443 \mathrm{mg} / 100 \mathrm{gm})$, the magnesium content of probiotic chocolate was $(487 \mathrm{mg} / 100 \mathrm{gm})$, the iron content of probiotic chocolate was $(22.5 \mathrm{mg} / 100 \mathrm{gm})$, and the zinc content of probiotic chocolate was $(2.80 \mathrm{mg} / 100 \mathrm{gm})$. These values were found similar with the mineral content of control chocolate (without LAB) reported by Sager (2012).

\section{Sensory Evaluation of probiotic chocolate}

The sensorial quality characteristics of probiotic chocolate play a vital role in attracting consumers to purchase the product. Consumer judge's the quality on the basis of its sensory parameters such as color, taste and flavour etc. Sensory analysis was carried out to standardize the preparation of probiotic chocolate. The organoleptic evaluation was done using hedonic scale rating and the obtained mean score values for sensorial characteristics are shown in Table 3.

It is evident from the Table 3 that among various sensory characteristics color, flavor and taste were significantly affected by the various levels of log concentration of starter culture i.e. Lactobacillus acidophilus and Lactobacillus bulgaricus ranging from $10^{7}$ to
$10^{9} \mathrm{cfu} / \mathrm{gm}$ and its incubation time period 10 hr. Color serves as a preliminary parameter for the acceptance of food. Color is an important sensory parameter concerning the consumer's acceptability of chocolate. The results showed in Table 3 showed that acceptable color was observed in sample C and containing $10 \%$ of Lactobacillus acidophilus and Lactobacillus bulgaricus with $\log$ concentration $10^{9} \mathrm{cfu} / \mathrm{gm}$ with $10 \mathrm{hrs}$ incubation period. The maximum score for color of chocolate in treated sample was obtained by sample C (i.e.8.5). Flavor means an overall integrated perception of taste and aroma associated with the product (Meilgaard et al., 2007). The results in Table 3 revealed that the chocolate sample $\mathrm{C}$ got significantly higher score (i.e.8.8). However, the lowest score (i.e.7.6) for the flavor was given to control sample. It was observe that functional foods had first of all to taste good and then offer health benefits conveniently to the consumer. Maximum score for taste was noted in the sample C followed by B and A. The addition of the encapsulated beads of Lactobacillus acidophilus and Lactobacillus bulgaricus did not change the taste of chocolate.

\section{TPA of probiotic chocolate}

The hardness of different samples of chocolate was analyzed by using texture analyzer with $2 \mathrm{~mm}$ Cylinder probe $\mathrm{P} / 2$ using $5 \mathrm{~kg}$ load cell and expressed in terms of maximum peak force $(\mathrm{kg})$. The results obtained regarding the hardness of different chocolate samples are showed in Table 4. Texture (hardness) is a group of physical characteristics, sensed by mouth bite. Maximum textural score (i.e.4.5) was secured by Control sample, followed by sample $\mathrm{A}$ (i.e.3.4), while the minimum score (i.e. 2.1) was observed in sample B. The data showed in Table 4 revealed the hardness values of different chocolate samples. Control sample 
i.e. without encapsulated LAB showed highest values for hardness $(4.5 \mathrm{~kg})$ and lowest hardness recorded was of sample B $(2.1 \mathrm{~kg})$. It is followed by sample A and C had hardness values $(3.4 \mathrm{~kg}$ i.e. and $2.7 \mathrm{~kg}$ ) respectively. These values indicate that the hardness of chocolate that does not contain encapsulated $\mathrm{LAB}$ was slightly higher than those contains encapsulated LAB.

\section{Overall acceptability}

Overall acceptability is based on multiple organoleptic quality parameters i.e. color, flavor, taste, texture etc. and shows the accumulative perception and acceptance by the panelists. Addition of encapsulated microorganisms like Lactobacillus acidophilus and Lactobacillus bulgaricus did not change the sensory attributes of chocolate.

The maximum score (i.e.8.8) for overall acceptability was observed in sample $\mathrm{C}$ having 10\% Lactobacillus acidophilus and Lactobacillus bulgaricus starter culture with $\log$ concentration $10^{9} \mathrm{cfu} / \mathrm{gm}$ with $10 \mathrm{hrs}$ incubation period while the minimum score (i.e.7.9 and 8.3) was observed in sample A and $\mathrm{B}$.

Table.1 Chemical Analysis of probiotic chocolate

\begin{tabular}{|l|c|}
\hline \multicolumn{1}{|c|}{ Parameter (\%) } & Values \\
\hline Moisture & 5.64 \\
\hline Crude fat & 31.73 \\
\hline Crude Protein & 6.81 \\
\hline Crude fiber & 2.43 \\
\hline Ash & 2.12 \\
\hline Carbohydrate & 51.27 \\
\hline
\end{tabular}

Table.2 Mineral analysis of probiotic chocolate

\begin{tabular}{|l|c|c|c|c|c|}
\hline \multirow{2}{*}{\multicolumn{1}{|c|}{ Sample }} & \multicolumn{4}{|c|}{ Mineral composition of Probiotic chocolate (mg/100gm) } \\
\cline { 2 - 6 } & Calcium & Magnesium & Iron & Zinc & Manganese \\
\hline Control & 1451 & 490 & 21.2 & 9.16 & 2.84 \\
\hline Probiotic chocolate & 1443 & 487 & 22.5 & 10.1 & 2.80 \\
\hline
\end{tabular}

Table.3 Sensory Evaluation of probiotic chocolate

\begin{tabular}{|c|c|c|c|c|c|}
\hline Samples & Colour & Flavour & Taste & Texture & $\begin{array}{c}\text { Overall } \\
\text { acceptability }\end{array}$ \\
\hline Control & 7.8 & 7.6 & 7.6 & 7.5 & 7.7 \\
\hline A & 8.2 & 7.8 & 7.5 & 7.6 & 7.9 \\
\hline B & 8.4 & 8.4 & 8.2 & 8.0 & 8.3 \\
\hline C & 8.5 & 8.8 & 8.8 & 8.5 & 8.8 \\
\hline SE \pm & 0.0881 & 0.0816 & 0.1040 & 0.0957 & 0.0955 \\
\hline CD at 5\% & 0.2640 & 0.2448 & 0.3110 & 0.2871 & 0.02862 \\
\hline \multicolumn{5}{|c}{} \\
* Each value is average of three determinations \\
\hline
\end{tabular}


Table.4 Textural (hardness) properties of probiotic chocolate

\begin{tabular}{|c|c|}
\hline Particulars & Hardness (kg) \\
\hline Control & 4.5 \\
\hline A & 3.4 \\
\hline B & 2.1 \\
\hline C & 2.7 \\
\hline SE \pm & 0.03536 \\
\hline CD at 5\% & 0.1037 \\
\hline
\end{tabular}

* Each value is average of three determinations

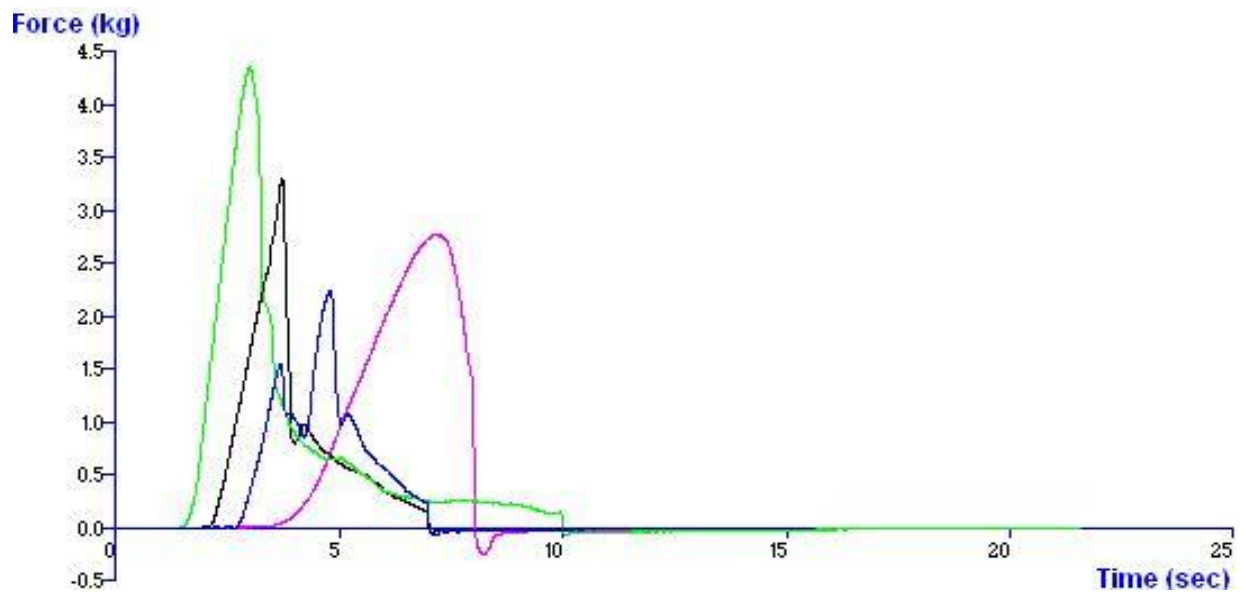

Table.5 Microbial analysis of probiotic chocolate during storage

\begin{tabular}{|c|c|c|c|}
\hline Time in Weeks & $\begin{array}{l}\text { Total Plate Count } \\
\text { (cfu/gm) } \times 10^{8}\end{array}$ & $\begin{array}{l}\text { Yeast \& Mould Count } \\
\quad(\mathrm{cfu} / \mathrm{gm}) \times 10^{3}\end{array}$ & $\begin{array}{c}\text { Coliform Count } \\
(\text { cfu/gm }) \times 10^{3}\end{array}$ \\
\hline 1 & $2.3 \times 10^{8}$ & ND & ND \\
\hline 2 & $3.7 \times 10^{8}$ & $1.6 \times 10^{3}$ & ND \\
\hline 3 & $5.5 \times 10^{8}$ & $1.2 \times 10^{3}$ & ND \\
\hline 4 & $4.6 \times 10^{8}$ & $1.0 \times 10^{3}$ & ND \\
\hline
\end{tabular}

Microbial analysis of probiotic chocolate during storage

The prepared probiotic chocolate sample was further analyzed for microbial properties during storage up to 4 weeks. The accepted chocolate sample was subjected to microbial studies for total plate count, yeast and mould count and coliform growth during the storage period as per method adopted by Cappuccino and Sherman, (1996). The results recorded during the investigation are presented in Table 5 along with photographs of petriplates showing results of total plate count, yeast and mold count and coliform count.

The accepted sample was subjected to microbial studies for total plate count, yeast and mold count and Coliform growth during the storage period as per method adopted by Cappuccino and Sherman, (1996). The results recorded during the present investigation are 
presented in Table 5. Yeast counts were strongly correlated with LAB count. Cometabolism between yeast and LAB may exist, where the bacteria provide the acid environment, which selects the growth of yeast, that in turn; provide vitamins and other growth factors to the bacteria. The progressive decrease in yeast and mold count might be due to resultant increase in acidity during storage.

The results from Table 5 also shows that, the chocolate sample was free from Coliform and $E$. coli when the sample was fresh and throughout the storage period of 4 weeks at refrigerator temperature $\left(4^{\circ} \mathrm{C}\right)$ as result of good hygienic and sanitary conditions, during the preparation of the chocolate.

In conclusion, the trend to enrich new foodstuffs with live Lactobacillus cells is a novel and promising approach to the application of LAB in the food production. The supplementation of chocolate with encapsulated live LAB cells is one of these new applications. Thus in the light of the scientific data of the present investigation, it can be concluded that milk chocolate was a good carrier for Lactobacillus acidophilus and L. bulgaricus cells. The organoleptic evaluation during storage study suggests that the product can be kept for one month under refrigerated storage $\left(4^{\circ} \mathrm{C}\right)$ without deterioration in taste and flavor. Also considering the high viable cell count $\left(10^{9} \mathrm{cfu} / \mathrm{ml}\right)$ even after 4 weeks of storage. The process of preparation of probiotic chocolate can be techno-economically feasible, justifies the suitability of chocolate as a carrier for in microencapsulated mixture of probiotic Lactobacillus acidophilus and Lactobacillus bulgaricus. Chocolate is willingly consumed by children and teenagers. The supplementation of this product with encapsulated live probiotic cells can enrich their snacks.

\section{References}

A.O.A.C.(2000). Official methods of analysis, Association of Official Analytical Chemists. Washington DC.

A.O.A.C.(1990). Official Methods of Analysis. Ternds Food Science Technology. Association of Official Analytical Chemists, Washington DC, USA.

Anuradha S. And Rajeshwari K. (2005). Probiotics in health and disease. Journal, Indian Academy of Clinical Medicine, 6(1): 67-72.

Burgain, J., Gaiani, C., Linder, M., and Scher, J. (2011) Encapsulation of probiotic living cells: From laboratory scale to industrial applications. J. Food Eng. 104, 467-483.

Cardarelli, H. R., Aragon-Alegro, L. C., Alegro, J. H. A., de Castro, I. A. and Saad, S. M. I. (2008), Effect of inulin and Lactobacillus paracasei on sensory and instrumental texture properties of functional chocolate mousse. J. Sci. Food Agric., 88: 1318-1324.

Cappuccino, J. G., and Sherman, N., (1996). Microbiology: a laboratory manual. The Benjamin cummings publication, Co. Inc. NY.

Ndife Joel, Bolaji Pius, Atoyebi Deborah and Umezuruike Chris. (2013).American journal of food and nutrition, 3(1): 3138.

Ieggli, C., Bohrer, D., Nascimento, P. and Carvalho, L. (2011). Determination of sodium, potassium, calcium, magnesium, zinc and iron in emulsified chocolate samples by flame atomic absorption spectrometry. Food Chemistry, 124:1189-1193.

Iyer, C. and Kailasapathy, K. (2005). Effect of co-encapsulation of probiotics with prebiotics on increasing the viability of encapsulated bacteria under in vitro acidic and bile salt conditions and in 
yogurt. Journal of Food Science, 70: M18-M23.

Krasaekoopt, W., Bhandari, B., and Deeth H. (2003). Evaluation of encapsulation techniques of probiotics for yoghurt. Int. Dairy J. 13, 3-13.

Maillard, M., and Landuyt, A., (2008). Chocolate: an ideal carrier for probiotics. Agro Food Industry Hi-Tec, 19 (3 Suppl.), 13-15.

Morton. J. F. (1987) Fruits of Warm Climates. Winterville, N.C.: Creative Resource Systems.
Nazzaro, F., Orlando, P., Fratianni, F., and Coppola, R. (2012) Microencapsulation in food science and biotechnology. Curr. Opin. Biotechnol. 23, 182-186.

Steinkraus, K. H. (1996). Handbook of indigenous fermented foods, 2nd ed. Reviews and Expanded, Marcel Dekker, New York.

Urala, N. and Lahteenmaki, L. (2007) Attitudes behind consumers willingness to use functional foods. Food Quality and Preference. 15(7): 793-803.

\section{How to cite this article:}

Sawale, K.R., H.W. Deshpande and Katke, S.D. 2019. Exploration of Bael (Aegle marmelos) Fruit Extract as Prebiotic for Development of Probiotic Chocolate. Int.J.Curr.Microbiol.App.Sci. 8(04): 1359-1367. doi: https://doi.org/10.20546/ijcmas.2019.804.158 